\title{
Socio-economics of mangrove ecosystem in South- eastern Ayeyarwady Delta area of Myanmar
}

\begin{abstract}
Coastal communities are dependent on the resources available in mangrove ecosystems. The loss of these ecosystems would mean local, national and global welfare losses. Healthy mangrove ecosystems were related with integrated ecological and economical processes by local people. In the present study, uses of mangroves, products and the fishery status of local areas have been studied. The mangrove forests from the study areas provide charcoal, firewood, food and some medicinal plants for local people. To assess the economic value of the regions, the local people from three villages who lived in and near the mangrove forest were questioned and documented. The households studied were categorized into three groups such as poor, middle and rich class and then their monthly income and kinds of jobs studied. The products and works based on mangrove forest and water ways of study areas were the production of Nipa thatches, dried fishes, dried shrimp, nga-pi, pickled shrimp, shrimp sauce and charcoals.
\end{abstract}

Keywords: Ayeyarwady delta, Nipa thatches, nga-pi, pickled shrimp
Volume 8 Issue 6 - 2019

\author{
Kyi Kyi Myint \\ Department of Botany, University of Magway, Myanmar
}

Correspondence: Kyi Kyi Myint, Associate Professor, Department of Botany, Magway University, Myanmar, Email Kyikyimyntbotany@gmail.com

Received: November 14, 2019 | Published: December 03, 2019

\section{Introduction}

Mangrove forests were crucial of significance for local people, providing food, shelter and, medicinal and other uses. The local people depend on mangroves for fire-wood, charcoal, timber, poles and many other purposes. Traditional uses of mangrove resources currently continue side by side with large-scale and intensive exploitation using high-capital investment and technologies such as charcoal production and firewood. In recent years, efforts to convert mangrove land for other uses, such as fish- or shrimp-ponds or industrial and human settlements have been increasing in number and size. Nevertheless, mangrove provided directly and indirectly uses in various ways. The mangrove forests provide livelihood and employment to wood cutters, fishermen, honey and wax collector, shell collectors, timber traders and their workers and other peoples who work both seasonally and round the year in the forest.

Mangrove forests have been traditionally utilized by the local people for a variety of purposes. Values of mangroves are recognized as "tangible" and "intangible" benefits. The mangrove forest ecosystem is capable to yield the following direct benefits: poles, fuel wood, fishing gear, etc.; raw materials for the wood-based of various industries and charcoal products, etc.; non-timber products including tannin (mostly from bark) to supply raw materials for fishing net processing units, thatching material for roofing and raw materials for indigenous medicine; edible products including honey and wax, meat and fish, fruits and drinks. The mangrove ecosystem can yield the following indirect benefits: natural spawning ground for fish, shrimps and crustaceans, prawns, and conservation of wildlife habitats, and control and regulate the food chain in stores. Mangrove forests contribute to mud flat formation and control of erosion; capability to check inland salinity intrusion; enhance capability to combat the impact of cyclone and tidal surge; and capability to function as a shelter belt during storms and cyclones.

The mangrove ecosystem is a complex one. It consists of water, muddy soil, trees, shrubs and their associated flora, fauna and microbes. It is a very productive ecosystem sustaining various forms of life. For most of the mangrove areas of the world, "fishery" and "forestry" are the two conflicting demands on mangrove lands. Apportioning of the mangrove land resource to these two major uses under the concept of sustainable management of the ecosystem needs further research though a ratio of 20:80 is suggested for ponds to mangroves, on 25 ha allocations as "woodlot silvo-fishery" by Choudhury 1996.

Many kinds of impact caused by human activities have affected the mangrove areas. The total mangrove forest area has been reduced, with resultant deterioration in the coastal environment and declined by $1 \%$ annually. Deforesting of the mangrove areas is mainly related to economic and development activities. So, to obtain the information is fundamental and important requirement for their conservation and management principles on these ecological, bio-resource systems, economical and socio-cultural functions of this region. It is necessary to know the important multiple roles in the socio-economic life of the local people. The economic value of mangrove areas from the Southeastern Ayeyarwady Delta has been studied. The purpose of the study is to know the uses of mangrove directly and indirectly, and the livelihoods of local people who depend mainly on mangrove.

\section{Literature review}

Mangrove forests are extremely important coastal resources, which are vital to socio-economic development. So many literatures and references are available for the socio-economy of the mangrove regions. Kathiresan and Bingham ${ }^{1}$ reported that the mangroves are sources of highly valued commercial products and fishery resources and also as sites for developing a burgeoning eco-tourism. Dixon and Lucy $^{2}$ also reported that the mangrove forests have been shown to sustain more than 70 direct human activities, ranging from fuel-wood collection to fisheries.

Hong and $\operatorname{San}^{3}$ reported that many mangrove species are used as timber and Rhizophoraapiculata and Bruguieraparviflora are preferred species for piling purposes. Rhizophoraapiculata and Bruguieraparviflora are converted into charcoal, which constitutes the main mangrove product in south coastal delta. They also mentioned that the rapid population growth, especially in coastal area, has resulted in greater demand for fuel wood and housing materials. 
Forest Department (1991-92) stated that the Sundarbans mangrove play an important role in the economy of the south western region of Bangladesh. Total production of fishes over a year period has been calculated as $14562,370 \mathrm{~kg}$. The productions of dry fishes are recorded as 16,843 mounds. The annual production of shells is approximately 3,330,000kg. ${ }^{4}$ Extrapolated estimates of the total yield of commercial species of fish in 1993 was 1894 tonnes. However, for the year 1993, Chantarasri ${ }^{5}$ estimates a much higher total shrimp catch of 1,453 million with 334 million caught inside the forest area and the remaining 1,119 million collected from outside the forest area. The production of crabs as recorded by Forest Stations has increased from 278 tonnes in 1991-91 and 312 tonnes in 1992-93.

Husssin and Acharya $^{6}$ mentioned in his book, that Heritierafomes is the principal timber species in the Sundarbans and other timber species of commercial importance are Sonneratiaapetala, Xylocarpusmekongensis, Avicenniaofficinalis and Bruguieragymnorhiza. The two major fuel wood species in the Sundarbans are Heritierafomes and Ceriopsdecandra. Other species which also provide good qulity fuelwood. These include Amooracucullata, Aegicerasmajus, Rhizophoramucronata, Hibiscustilliaceus, Ceriopscandellana and Cynometraramiflora. Approximately 17,000 hectares are exploited annually. H. fomes fuelwood are used as raw material for the manufacture of hard boards. Leaves of Nypafruticans is a major source of thatching material in southwest Bangladesh.

Constanza et al. ${ }^{7}$ reported that studies thus far have focused in on direct benefits of mangrove ecosystems such as fisheries, timber, fuel wood, and tourism and there have been some attempts at indirect benefits such as coastal protection. He estimated that the total annual economic value of mangroves at more than US\$900 000perkm². Many workers have studied the products and their utilization of mangroves forest. Brown ${ }^{8}$ stated that the ecology of coastal lands and coastal waters provides numerous livelihood opportunities, encouraging concentrations of population and development activities. Himilton ${ }^{9}$ also reported that mangroves provide opportunities for education, scientific research, recreation and ecotourism. Mangroves have multiple uses. These are important sources of products such as timbers, various kinds of poles, firewood, charcoal, Nypa thatch, sugar, honey, paper-pulp, tennin, oil and many other living products such as fishes, shrimps, crabs, crocodiles, oysters etc. which are exploited by the riverine populations on a local scale and a global scale. Bandaranayake ${ }^{10}$ reported that Rhizophoraapiculata provides charcoal and has very high caloric value, burns very slowly and produces virtually no smoke. Kathiresan ${ }^{11}$ reported many uses of mangrove extracts and stated that the extracts from the mangroves seemed to have a potential for human, animal and plant pathogens and for the treatment of incurable viral diseases like HIV.

Many workers from Myanmar also reported the utilization and socio-economy of the mangrove plants. Malar ${ }^{12}$ focuses on the status of mangrove resource uses in Myeik Coastal Zone. Based on 1000 households in 10 villages sited in mangrove areas, utilization of mangrove ecosystem resources were $15 \%$ with direct uses and $85 \%$ with indirect uses. 5\% of timber harvesting used Xylocarpousgranatum, Heritieralittoralis, Avicennia alba; 5\% of fire wood utilized for Rhizophoraapiculata, $R$. mucronata, Bruguieraparviflora and $5 \%$ charcoal processing come from Rhizophoraapiculata, $R$. mucronata, and Bruguieraparviflora. $70 \%$ of fishing caught are from Scyllaserrata, Sessamabiden, Acetesindicus, Penaeusmonodum, $P$. merguiensis, Octopus, oysters, mussel, cockle, shrimp and crab. 20\% of mangrove resources are used as aquaculture.

San ThaTun ${ }^{13}$ also reported the economic uses of mangrove in Chaung Tha coastal area. He found that Rhizophoraapiculata, $R$. mucronata, Bruguieraspp., Ceriops spp. and Avicennia spp. are used as charcoal making. Charcoal production is approximately $166,000 \mathrm{~kg} /$ year. Rhizophoraspp., Bruguiera spp., Ceriops spp., Avicenniaspp., A. coniculatum, $H$. fomes and Xylocarpous spp. are the mainly used for firewood.

\section{Materials and methods}

The assessment of economic value of mangrove for the local population from the Southeastern Ayeyarwady Delta has been carried out within the period of May 2015 to March 2016. Three times field surveys has been made. Data collections were made in the villages near mangrove areas. Some of the households who lived in and near the mangrove forests were interviewed. These households were interviewed with questionnaire surveys. The villages included Htaung Gyi Tan (Lat. $15^{\circ} 43^{\prime} \mathrm{N}$ and Long. 95 $15^{\prime} \mathrm{E}$ ), station (1), AhsheyHpyar (Lat. $15^{\circ} 43^{\prime} \mathrm{N}$ and Long. $95^{\circ} 22^{\prime} \mathrm{E}$ ), station (2), and Nauk-mee (Lat. $15^{\circ} 47^{\prime} \mathrm{N}$ and Long. $95^{\circ} 28^{\prime} \mathrm{E}$ ), station (3), from the Southeastern Ayeyarwady Delta, Myanmar. The households who lived in three villages were categorized into three groups, namely: poor, middle and rich class. 30 interviewers were chosen and utilized to obtain the necessary information required by the communities for planning and decision making. (Figure 1)

\section{Results}

\section{Mangroves as the economically important resources for local people}

\section{Charcoal making}

The mangroves of Ayeyarwady Delta were primarily used for the production of charcoal since Second World War. It is known that many acres of mangrove areas are depleted by charcoal making in Ayeyarwady Delta. The timber used for charcoal production included Avicennia, Ceriops,Bruguiera and Cynometra which are best timber for charcoal making. So, the timber production from mangrove regions is becoming rare. Instead, small plants and associated plants were dominated as the secondary vegetation within the mangroves.

Nowadays, the mangrove species Brownlowiatersa and Excoecariaagallocha are used for the charcoal production which is being replaced in the mangroves. Although the plants are small, the trunks of Brownlowiatersa and Excoecariaagallocha were being used as charcoal.

The trunks are cut into 2 feet long and 2 inches in diameter. One bundle of these species was bought by 40 kyats. About 500 bundles were placed into kiln until it full of pieces for charcoal production. The kiln is dome shaped structure and make up of bricks, sand and clays. The kiln was then closed and the pieces were burned and baked. After 20 days, charcoal was completely produced and the kiln was opened to let the charcoal cool off. 10 viss of charcoal are put into one sac and sold by 1500 kyats. 40 sacs were got from one kiln and income money was 60,000 kyats. Two times per one month were made for production of charcoal. The sacs of charcoal had to be transported in Ahshey-Hpyar village and Ahmar Township. 


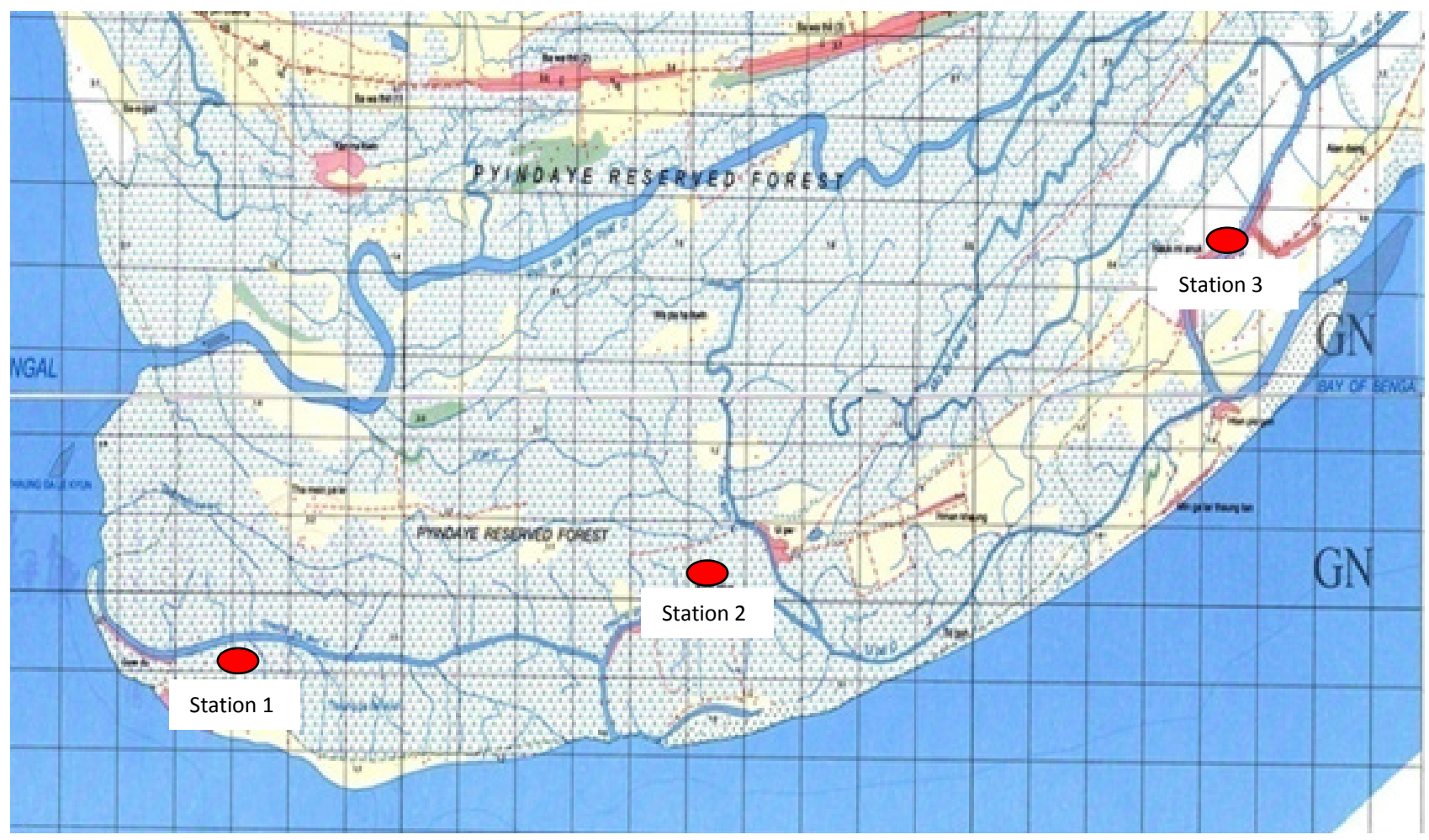

Figure I Map showing the study areas.

\section{Fuel wood}

The use of mangrove wood as a source of fuel for household and commercial purposes was fairly widespread. Nearly all families living in mangrove and surrounding areas depended on this ecosystem for firewood. Local people are classified the various mangrove woods for fuel as four classes: first class-Rhizophora, Bruguiera, Ceriops and Heritiera; second class-Sonneratia; third class -Xylocarpous and Aegiceras and fourth class -Avicennia, Sonneratia and Excoecaria. The woods of Avicennia, Heritiera and Excoecaria were used as fuel at every house. $100 \%$ of local people were directly used the mangrove forest as firewood in the villages. Local people cut the branches of the mangrove plants, pruning to use as firewood however, they don't cut clearly the main stem.

\section{Production of Nypa thatches}

One of the most important non-wood forest products is Nypa thatches for the local people. The species Nypafruticans are used as thatches. Moreover, the leaf stalks of Nypa are used as floats in fishery sector. The young fruits of Nypa are edible and are eaten by wood cutters, crab catchers and fuel wood collectors. Toddy can be obtained from the spa the of the Nypa plants.

Local people sell the Nypa thatches that a bundle of leaflets is locally known as a "pal". A pal of leaflet bundle included the leaflets from 50 leaves. 50 thatches can get from one pal. 100 thatches can sell about 3500 kyats. For a women, about 400 thatches can made by hand per day, their income are 100 thatches for 400 or $500 \mathrm{kyats}$. The Nypa that ches were also used as roof material for houses, boats and dwelling and for wall-partitioning. The products are not only used in the local but also sell to other regions. Leaflets of Nypa were also used to tie the crabs as a rope, not to move the crabs in crab fishery purposes.

\section{Construction materials}

Phoenixpaludosa is one of the representatives of mangrove region of high tide level. The plants are shrubs and the stems were used for frames of walls of the local houses, bridges and as poles. The leaves of Phoenix paludosa were also used as the first layer in roof-thatching and is an important material for local villagers in the vicinity of the mangrove forests. One pole of Phoenix can sellabout150kyats. A worker earns a bare living cut 20 poles of Phoenix plants, and canget 3000 kyats per day. The poles were also used to bake in the production of bricks.

\section{Other uses}

Some other products can also be used from the mangrove plants. The leaves of Avicennia officinalis are used as food for goats and cows. Roots of Meropeangulata(Taw-shauk) were also used as medicine that the paste of these plants is used to relief for patient who suffer stiffness in the muscle. The other uses are presented in tables1-2.

\section{Fishery purposes}

The mangrove ecosystem is one of the important sector for fisheries because it has high in nutrients and biodiversity richness which are then exploited locally mainly by artisanal fisher folk. Ayeyarwady Delta is also well known as the high potentials of fisheries status and has the rich nutrients for various fishery resources. So, near the mangrove areas serve as the important fishing grounds for the local fishermen. 
Table I Medicinal uses of mangroves in study areas

\begin{tabular}{|c|c|c|c|c|c|}
\hline No. & Mangrove plants & Local name & Parts & Process & Diseases/ailments \\
\hline I. & Clerodendroninerme & $\begin{array}{l}\text { Taw-kyaung- } \\
\text { pan }\end{array}$ & $\begin{array}{l}\text { Leaves, } \\
\text { fruits }\end{array}$ & Grind & $\begin{array}{l}\text { Be completely free from microbes } \\
\text { in human body }\end{array}$ \\
\hline 2. & Dolichandronespathacea & Yae-tha-khut & Leaves & Grind & To prevent the poison, venom \\
\hline 3. & Hygrophilaobovata & Pinle-hnan & Seeds & Mix with water & Abscess, pustule \\
\hline 4. & Meropeangulata & Taw-shauk & roots & paste & $\begin{array}{l}\text { Muscle, paralysed, sprain stiffness in } \\
\text { the muscle, muscular contraction }\end{array}$ \\
\hline 5. & Meropeangulata & Taw-shauk & Fruits, leaves & Mix with alcohol & Muscle, paralysed, sprain \\
\hline 6. & Plucheaindica & Khayu & Leaves & Leave salad & dysentery \\
\hline 7. & Xylocarpusgranatum & Pinle-ohn & seeds & paste & cancer \\
\hline
\end{tabular}

Table 2 Other uses of mangroves in study areas

\begin{tabular}{lllll}
\hline No. & Mangrove plants & Local name & Part s & Uses \\
\hline I. & Acrostichumaureum & Hnge-gyi-taung & Frond & Fried, salads \\
2. & Aegicerascorniculatum & Yae-kgayarr & Flower & Honey \\
3. & Avicenniamaina & Thame-phyu & Fruit & Food for Nga-dan (Silonia children) \\
4. & Avicenniaofficinalis & Thame-gyi & Seed & Foods for goats and cows \\
5. & Ceriopstagal & Madama-hmaw & Bark & Tanin \\
6. & Dalbergiaspinosa & Byaik, Su-gou & Leaves & Soap \\
7. & Derris trifoliata & New-net & Leaves & Salads, food for cow and buffalo \\
8. & Nypafruticans & Dani & Fruit, Leaves & Fruits edible,thatch for roof and wall \\
9. & Plucheaindica & Khayu & Leaves & Boiled with water for salads \\
I0. & Pongamiapinnata & Than-that & leaves & Boiled with water for salads \\
II. & Phoenoxpaludosa & Thin-baung & Bud & Food for men, soup \\
12. & Sarcolobusglobosus & Sa-moun-new & Leaves & Salads, soup \\
13. & Sonneratiaapetala & Kant-bala & Fruit & Edible, food for Nga-dan \\
\hline
\end{tabular}

The water of the Ayeyarwady Delta is usually brackish, being fed by saline sea water through the tides and fresh water coming from rivers and creeks that drain into the sea. Due to brackish condition, brackish species fishes are encountered in the areas. The fisheries of local people are based on fishes, shrimps, and crabs and to some extent algae, and also include wood product for fishing gear. Most of which are derived from mangroves.

\section{Dried shrimp production}

One of the incomes for the local people is to make dried shrimp production. Mostly are woman who are the main participated in dried shrimp production. The collected species of shrimps in the study areas are Penaeusmonodon, $P$. japonicus and $P$. indicus. The dried shrimp making is included the processes of boiling and drying.

One viss of shrimp species were boiled with water and put into one teaspoon of salt at 15 minutes. These boiled shrimps were taken on sun-dried for two days or put into the shelf and spread them and giving the fire under the shelf or smoked. The smoked or boiled shrimp were taken and put inside the sac and pounded with heavy stick to remove their heads, tails and scales. One viss of fresh shrimps were smoked to obtained10-15ticals of dried shrimp. Total production of 8,000-8,500viss of dried shrimp from Htaung-gyi-tan village over the dry period 2014-2015 has been obtained and 80,000-85,000viss from Ahshey-hpyar village, 160,000-165,000viss from Nauk-mee village were occured. These dried shrimp were transported to Pyapon Township and Rangoon Region. The price of this dried shrimp was about 15,000-28,000kyats.

\section{Production of dried and salted fishes}

Another economic of local populace is making the dried and salted fishes. The common fishes such as Cynoglossus lingua (Ngakhwae-shar) Latescalcarifer(Ka-ka-dit), Liza parsia(Ka-be-lu) and Plotosuscanius(Pin-lae-nga-khu) were made for dried and salted fishes in the areas. Squids are also used for dried. The fishes are directly sundried without washing or removing of viscera. Latescalcarifer(Ka- 
ka-dit), Liza parsia(Ka-be-lu), Plotosuscanius(Pin-lae-nga-khu) were washed and removed by viscera with the knife, and then salted by fishes for one night. On the next day, salted fishes are sun-dried for another two days. These dried and salted fishes were then stored in the air-tight jar for a long time.

\section{Production of "Nga-pi" or shrimp paste}

The production of Nga-Pi is also one of the local make economies in the areas. It is also the woman sector. As the villages were located on the river mouths and on the bank of creeks and nearby the mangroves, the local people commonly exploited the shrimps. Most of the shrimps are made Nga-pi or shrimp paste. Generally, the fish paste included the small shrimps (Acetesindicus), the mud crabs (Scylla serrata) and mangrove crabs (Sessamabiden); and many other kinds of fishes, shrimps, and other aquatic organisms are also included in the fish paste which are commonly occur in the study areas.

The small pelagic shrimp, Acetesindicus locally known as "Gway", was caught by push net, stationary bag net. Only the shrimp was sorted out and separated from the catches which contain many kinds of fishes by sieving. The shrimps were spread on the bamboo shelf for sun drying for 3 hours. The semi dry shrimp were mixed with salt and were put into the large wooden mortar and pounded with wooden pestle by hand until the shrimp and salt mixture become a soft and moist mass. Pounding and sun drying of the shrimp paste were repeated 2-3 times to get good color and delicate texture of Nga-pi. This shrimp paste or Nga-pi were stored or placed in the plastic bags or jars. After one month, the liquid was secreted from the bags or on the upper layer of shrimp paste. Secreted liquid known as nganpyar-ye,or shrimp paste sauce was used as condiment or seasoning in cooking meat or preparing salads.

\section{Making pickled shrimps}

Another economy is making pickled shrimps in the study areas. Half of aviss of fresh shrimps were removed by its crust to get fresh meat. The fresh meats were pound or assimilated by hand and mixed with 1 teaspoon of salt. And then, equal amount of cooked rice were

Table 3 Average monthly income according to the type of uses/workers

\begin{tabular}{|c|c|c|c|c|c|}
\hline Type & work & Price (Kyats) & & $\begin{array}{l}\text { Income per one } \\
\text { day(kyatsx days) }\end{array}$ & $\begin{array}{l}\text { Income per one } \\
\text { month (kyats) }\end{array}$ \\
\hline \multirow[t]{9}{*}{ Poor } & Collecting the snails & I viss $=4000$ & & $4000 \times 14$ & 56,000 \\
\hline & Collecting the crabs & $\mathrm{l} c r a b=250-1000$ & & $6,000 \times 14$ & 84,000 \\
\hline & $\begin{array}{l}\text { Cutting } \\
\text { wood }\end{array}$ & I bundle $=300-500$ & & $3,000 \times 30$ & 90,000 \\
\hline & Thatching & 100 thatches $=400$ & & $1600 \times 30$ & 48,000 \\
\hline & & Fish / Plants & Price & $\begin{array}{l}\text { Income per one day } \\
(\text { kyats } \times \text { viss } / \text { sac) }\end{array}$ & \\
\hline & & & & $8,000 \times 1.5=12,000$ & \\
\hline & & & & $5,000 \times 1=5,000$ & \\
\hline & & & & $3,000 \times 1.5=4,500$ & \\
\hline & & Penaeusindicus & I viss $=5,000$ & $600 \times 2=1,200$ & \\
\hline \multirow{4}{*}{ Middle } & & Latescalcarifer & I viss $=3,000$ & $600 \times 1=600$ & \\
\hline & Cast net, gill net & Pennahianea & I viss $=1,000$ & & \\
\hline & & Coiliaspp. & I viss $=600$ & & \\
\hline & & Epinephelussexfasciatus & I viss-600 & $24,300 \times 14$ days & 340,200 \\
\hline
\end{tabular}

pound or assimilated and mixed with 1 teaspoon of salt. A mixture of shrimp paste and cooked rice were mixed and kneaded. This paste was then placed into a piece of cloth and tightly binded and pressed with heavy metal or stone. After 3 days, pickled shrimp were obtained. This pickled shrimp were salad with one teaspoon of oil, sliced onions, chillies, power of chillies, powder of ground nut, power of dried shrimp and coriander and also fried with those.

\section{Ngapi sauces or fish sauces}

Ngapi sauces or fish sauces are also made in the study areas. The raw species include in Ngapi sauces are Leiognathusequulus(Nga-waing), Lepturacanthussavala(Nga-ta-khon), Satipinnawheeleri(Nga-parr), and Pennahianeu( Nga-poak-thin) or some fishes. Those fishes are not expensive ( 1 viss $=300 \mathrm{kyats}$ ). The fishes were placed into the water and soaked in it at one night. On the next day, the scales and gills were removed; the fish were gutted and cleaned with water 2 or 3 times. Then sieved to drain out water and placed to dry in the sun at 3 hours. This sun dried fish were mixed with salt and placed into the pot or glazed earthen jar and crammed or compressed. The congee was poured on the pot until the pot was full. Then it was sealed with a piece of cloth or laded with tray. After one month, the fish sauces were obtained.

\section{Local livelihoods and the utilization of mangroves}

The questioned survey on the economic condition from 30 households who depends on mangrove has been made. These households were categorized into three groups, namely, poor, middle and rich class (Table 3). For poor families, they were caught by crabs and snails and cutting the wood only. This is traditional work in mangrove area. However, their family income was limited to about 90,000-150,000kyats per month. Families of the middle had other kinds of jobs, such as fishing in the river or creek with nets or traps, shrimp aquaculture, small trading and brokerage of crabs and snails. The monthly income of these middle class families was about 200,000-550,000kyats per month each. The rich families earn approximately more than $30,000,000-40,000,000$ kyats per month. (Figure 2-13). 
Table Continued

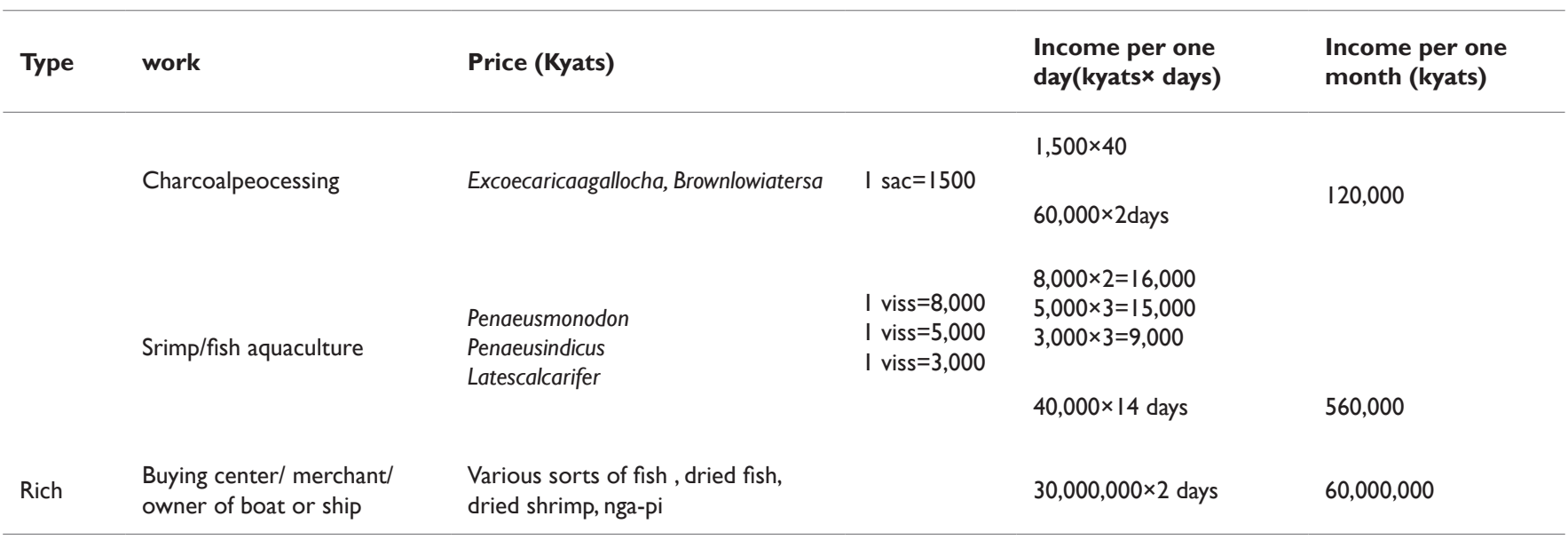
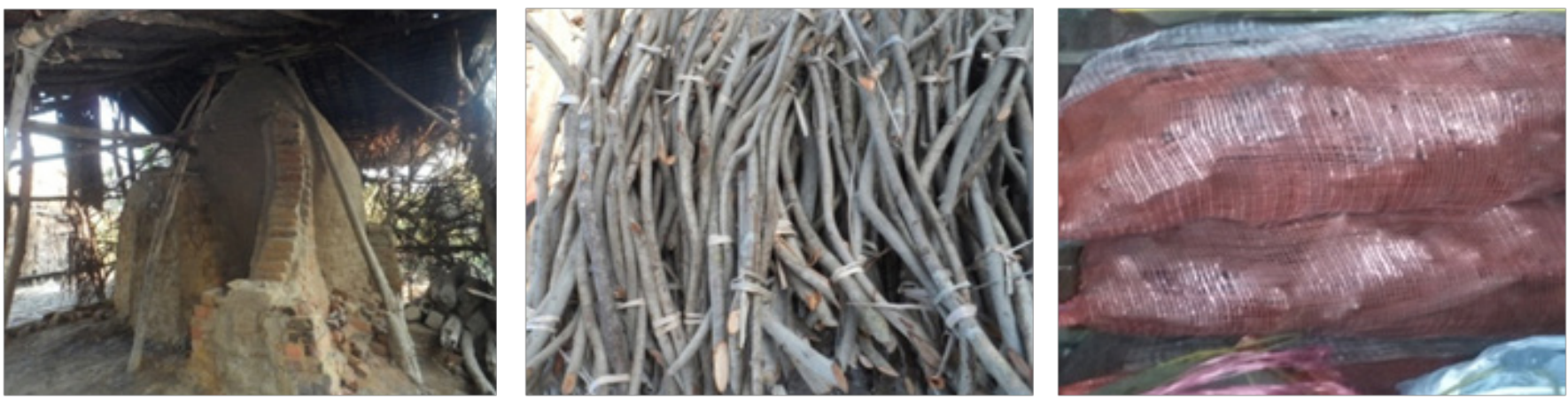

Figure 2 Making for charcoal: (A) Kiln. (B) wood and (C) sacks of charcoal.
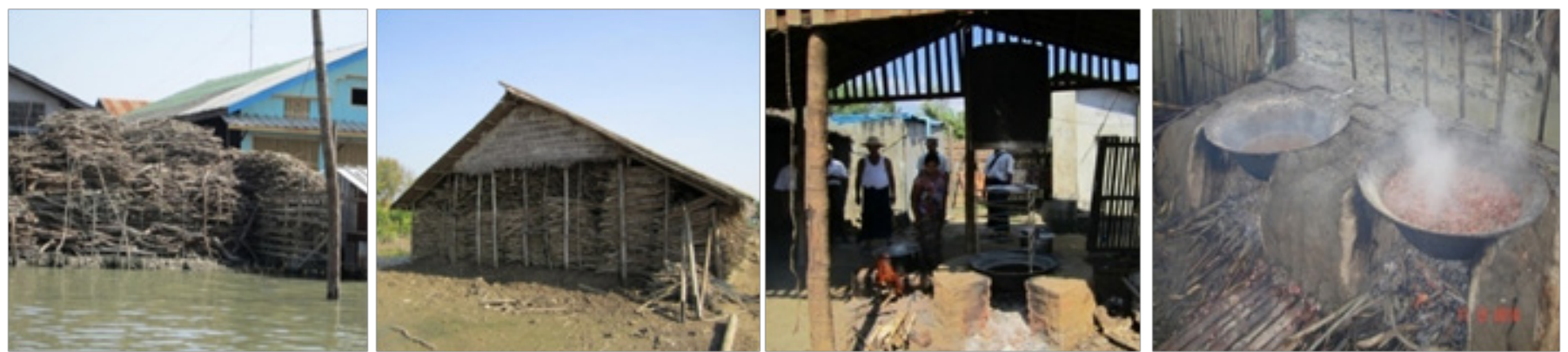

Figure 3 Uses of mangroves as firewood.
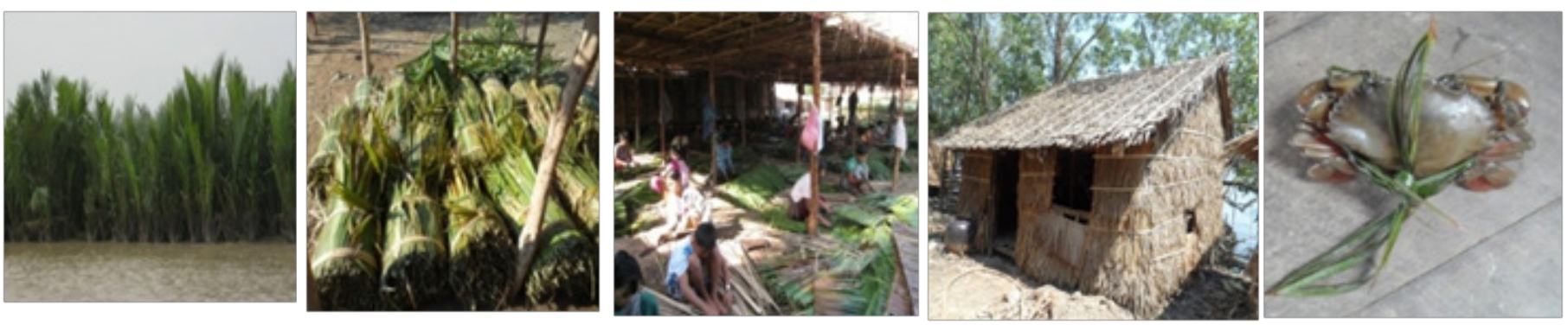

Figure 4 Uses of Nypafruticans.

Citation: Myint KK. Socio-economics of mangrove ecosystem in South-eastern Ayeyarwady Delta area of Myanmar.J Aquac Mar Biol. 2019;8(6):226-236. DOI: I0.15406/jamb.2019.08.00266 

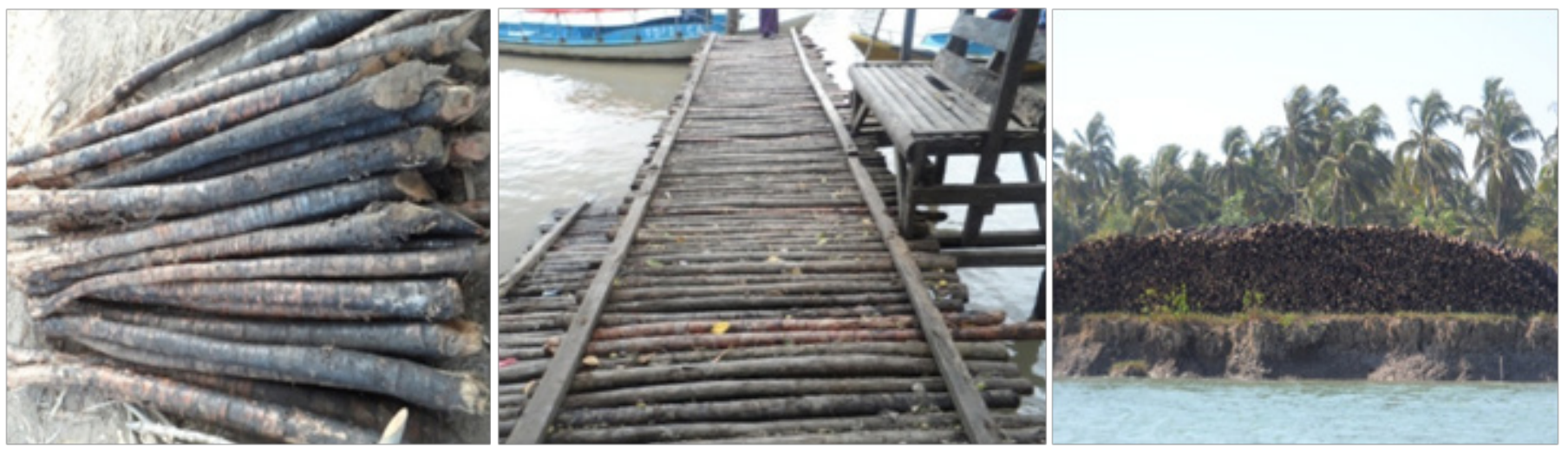

Figure 5 Uses of Phoenix paludosaas bridge and poles.
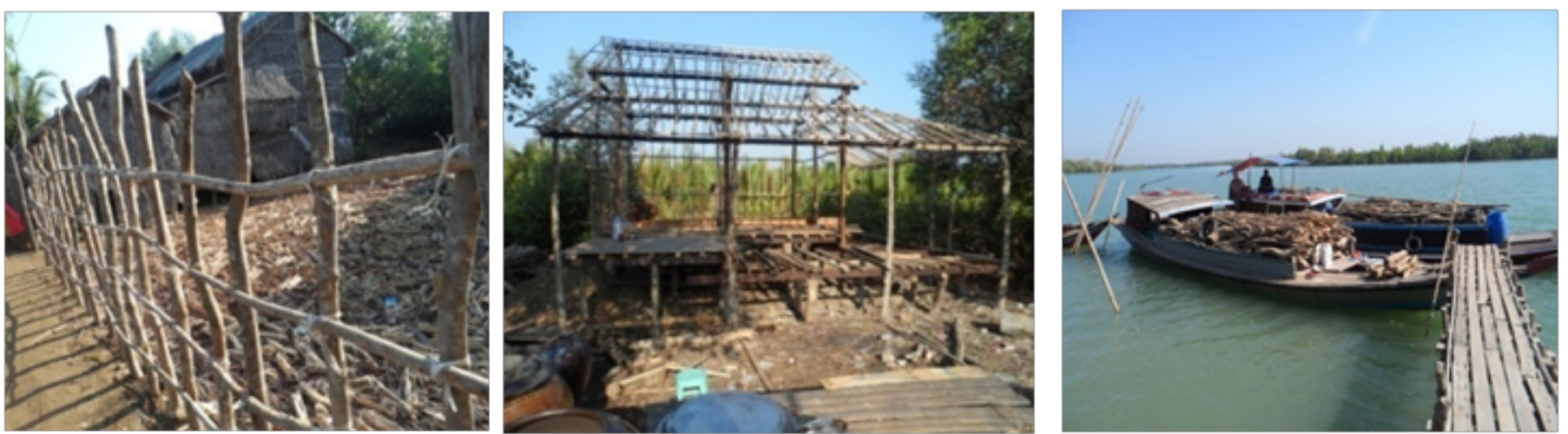

Figure 6 Uses of Avicenniaofficinalis as poles.
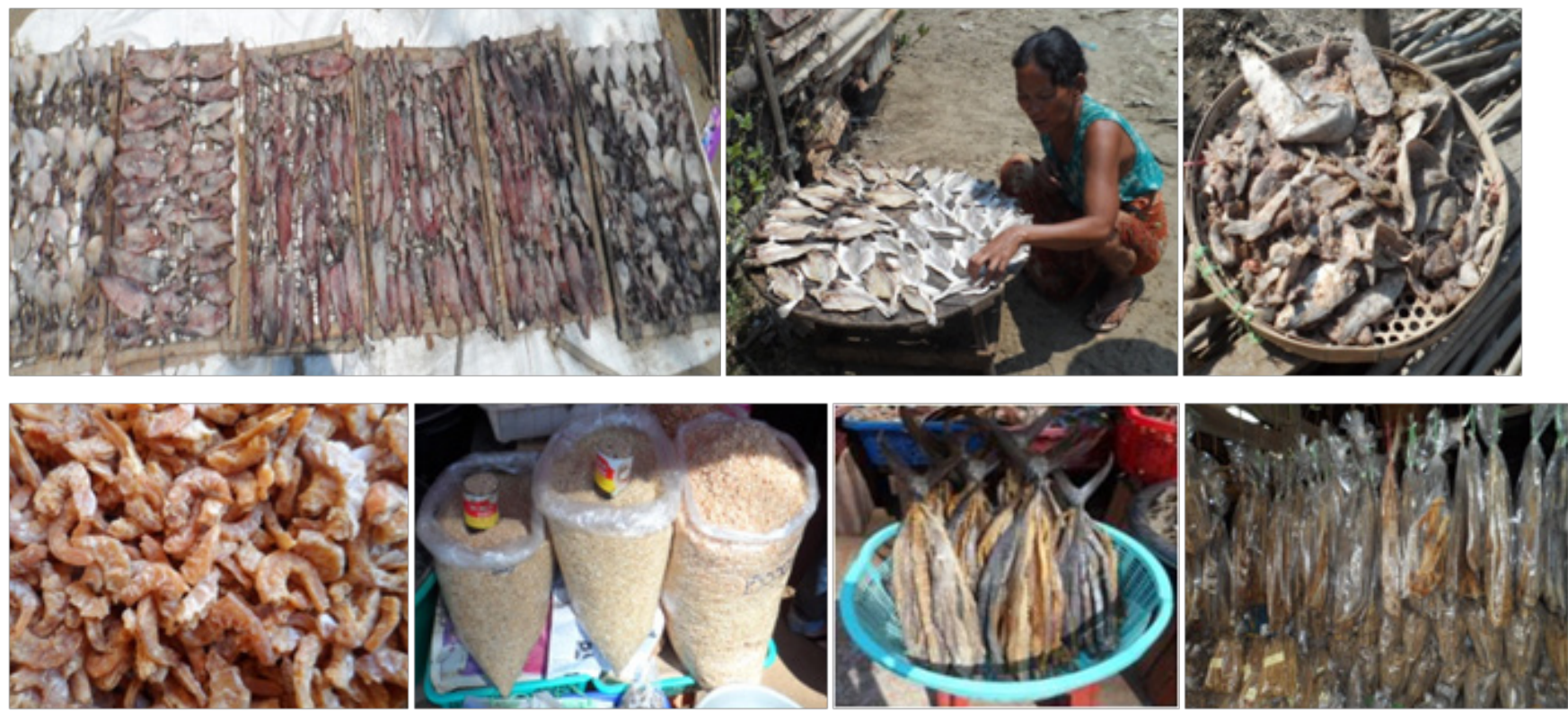

Figure 7 Dried fish and dried shrimp. 

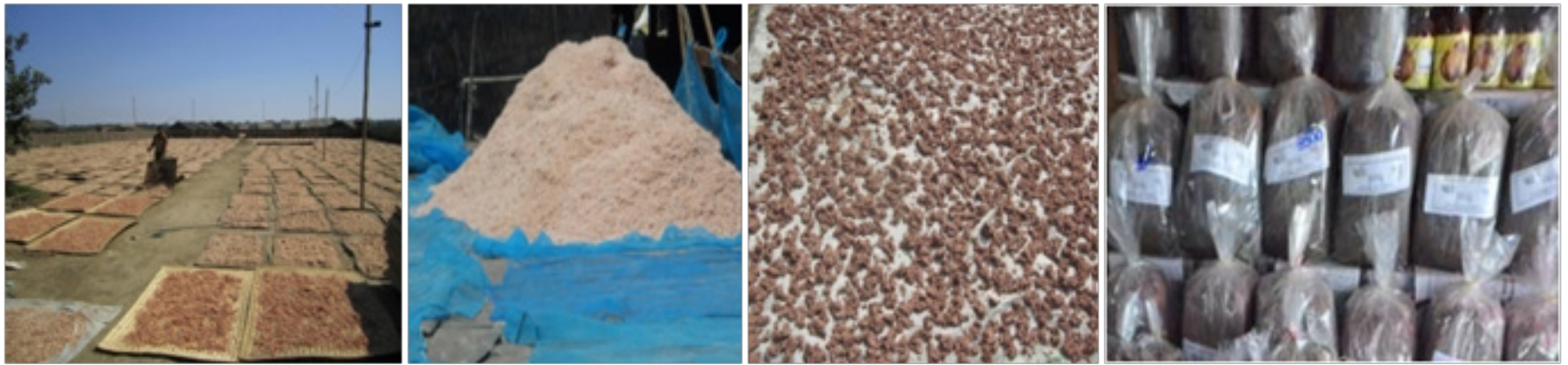

Figure 8 Production of 'Nga-pi” or shrimp paste.
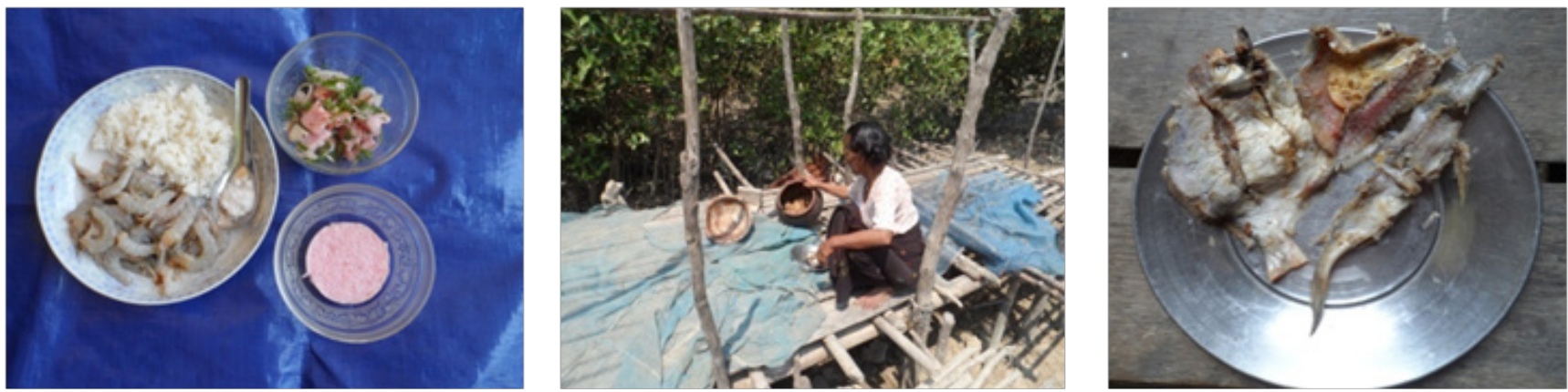

Figure 9 Pickled shrimp and Ngapi sauces or fish sauces.
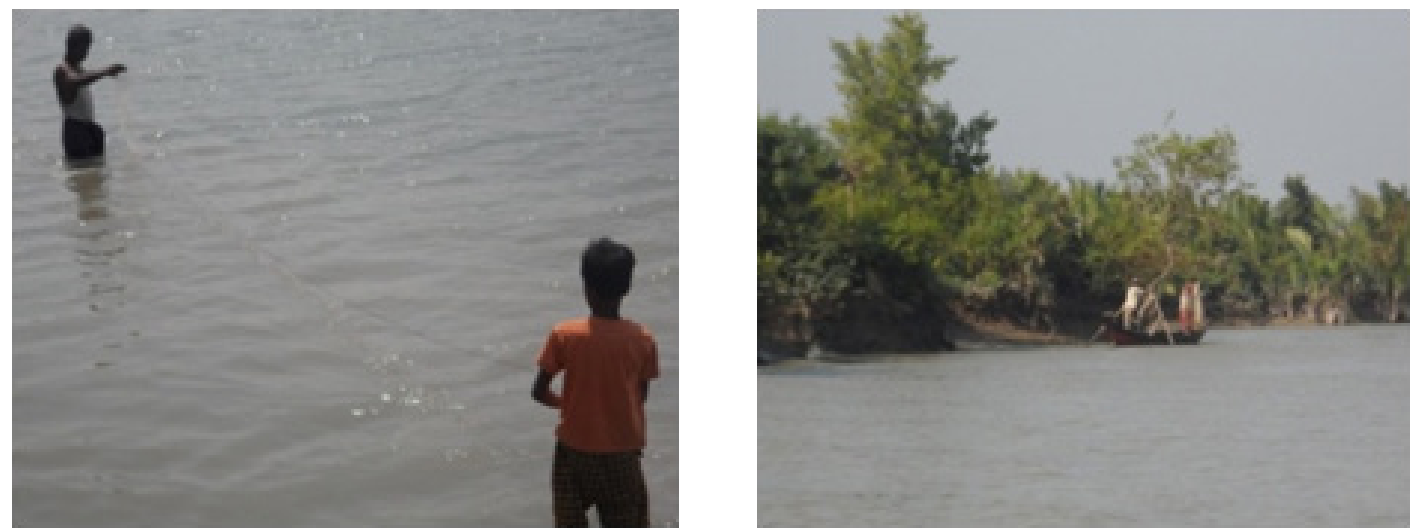

Figure 10 Catching fish by net.
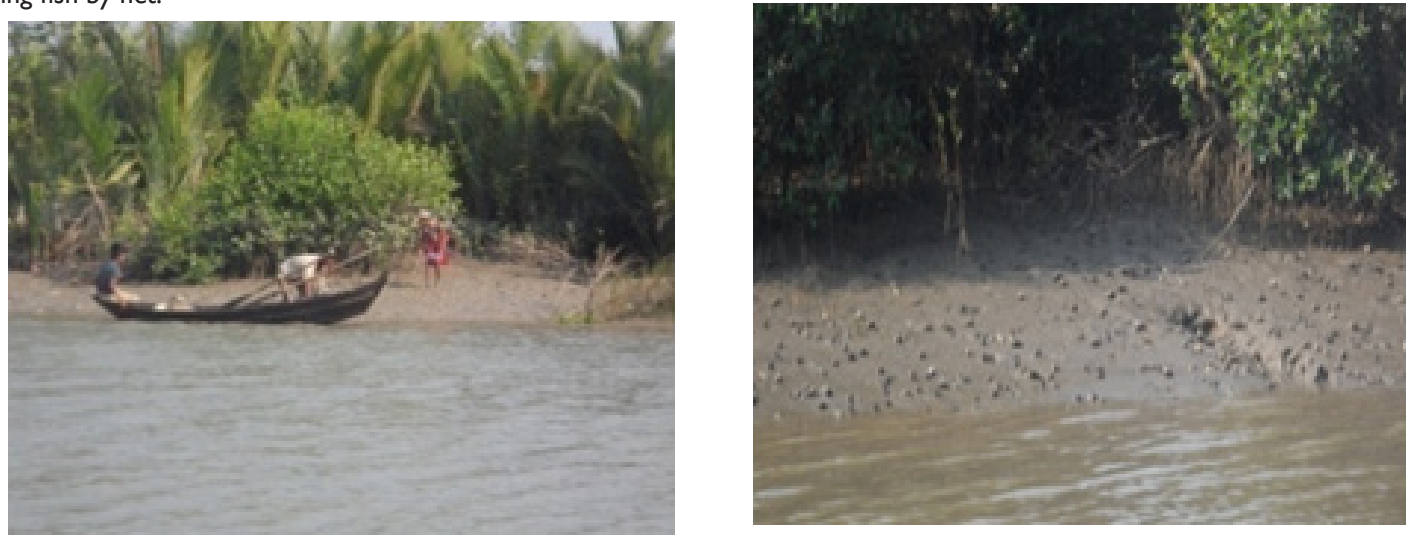

Figure I I Collecting the snail.

Citation: Myint KK. Socio-economics of mangrove ecosystem in South-eastern Ayeyarwady Delta area of Myanmar.J Aquac Mar Biol. 20I9;8(6):226-236. DOI: |0.15406/jamb.20|9.08.00266 

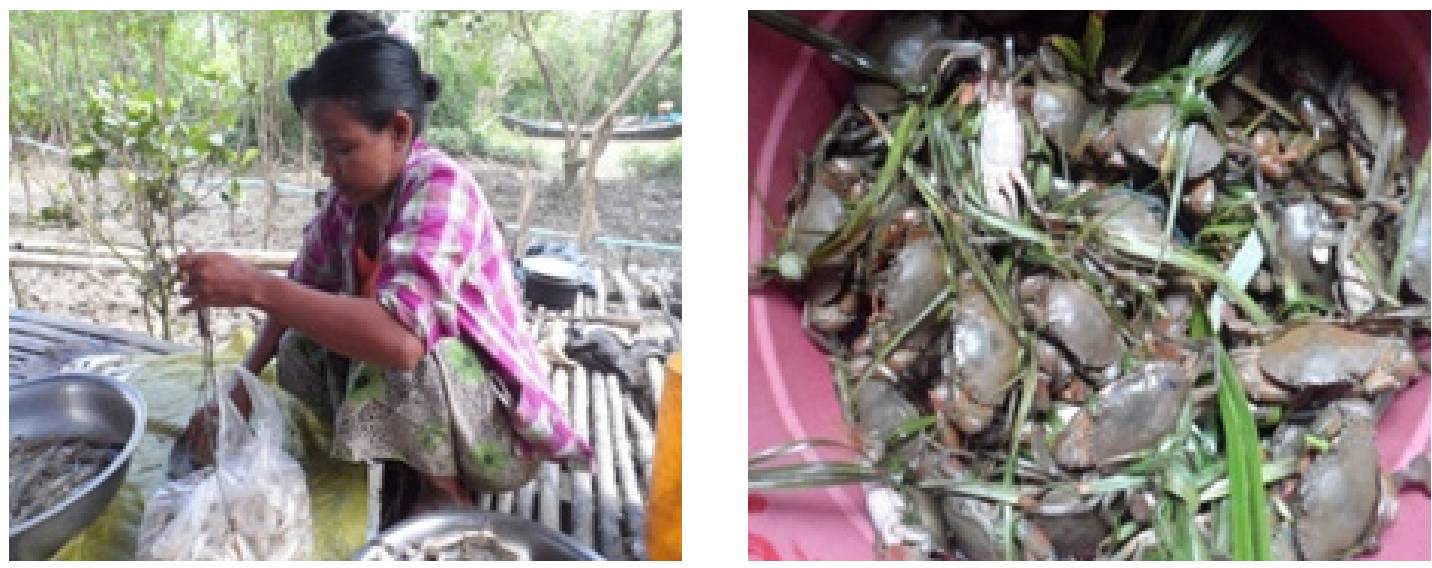

Figure 12 Selling the fish for income.
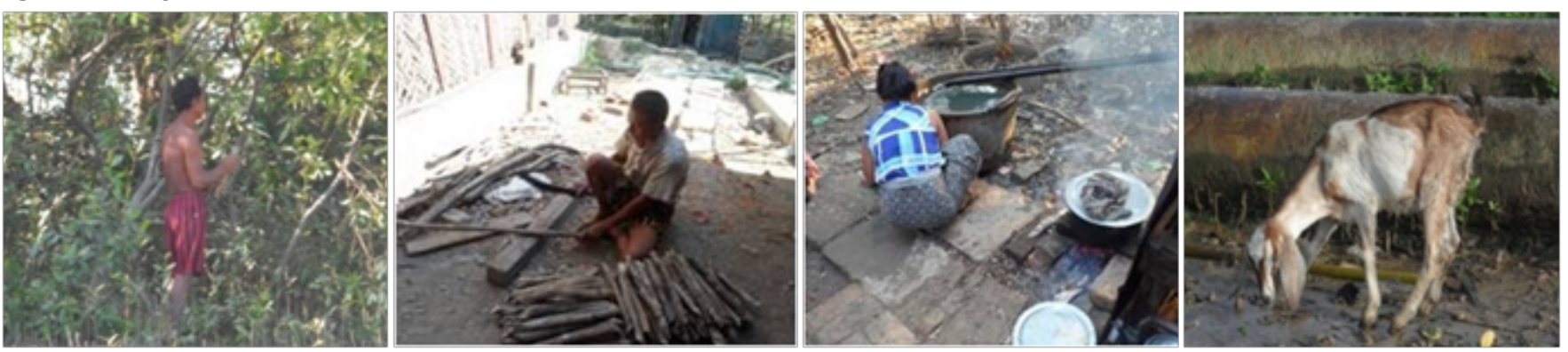

Figure I 3 Mangrove uses as fuel for households and as food for goat.

\section{Discussions}

Even though there are directly marketed products from mangroves, coastal communities continue to depend on mangroves for a range of goods such as fuel wood, shellfishes, palms and on ecosystesm services such as maintenance of the productivity of important estuarine dependent fisheries, water quality regulation, flood reduction and shoreline stability. Globally too, these products and services are valuable. Mangroves can provide vital nurseries for fisheries that support global communities and often shelter biodiversity of global importance by virtue of being, in general, relatively undisturbed ecosystems. Dixon ${ }^{2}$ stated that the mangrove forests have been used to human activities, ranging from fuel-wood collection to fisheries. In the present study, it was agreed that mangrove forest were useful for local people either directly or indirectly.

Hong and $\mathrm{San}^{3}$ reported that mangrove timber is very useful for structural purposes due to its durability. Rhizophoraapiculata and Bruguieraparviflora were used as timber in Sundarbans mangrove forest. In Ayeyarwady delta Rhizophoraapiculata, Avicenniaofficinalis, A. marina, A. alba and Bruguierasexangular were converted into charcoal since a long time ago. The charcoal kiln was dome-shaped structure make of bricks, sand and clay. Rhizophoraapiculata, which provides charcoal that has very high caloric value, burns very slowly, and produces virtually no smoke Bandaranayake. ${ }^{10}$ San ThaTun ${ }^{13}$ recorded that Rhizophoraapiculata, R. mucronata, Bruguiera spp., Ceriops spp. and Avicennia spp. are used for charcoal making. Now, Mangrove species of Brownlowiatersa and Excoecariaagallocha are also used for the charcoal production in this study areas. Nowadays, the mangrove areas are slowly declined because of human activities.
So the plants of secondary vegetation were used as charcoal and firewood.

Islam $^{4}$ and Chantarasri ${ }^{5}$ haved studied the total production of fishes, shrimps, dry fishes, the annual production of shells and crabs and were recorded from 1991 to 1993 . The present study revealed that the total production of dried shrimps at three villages and status of mangrove products were also studied. Annual production of dried shrimp for those villages was estimated about 160,000 Viss. So, the income of the local population is in good condition.

Heritierafomes is the predominantly principal timber species in the Sundarbans. Other timber species of commercial importance are Sonneratiaapetala, Xylocarpusmekongensis, Avicenniaofficinalis and Bruguieragymnorhiza. The two major fuelwood species in the Sundarbans are Heritierafomes and Ceriopsdecandra Husssin and Acharya. ${ }^{6}$ The present study revealed that Avicenniaofficinalis and Excoecariaagallocha are used as major timber species. Avicenniaofficinalis, Ceriopsdecandra and Excoecariaagallocha are the major species used in fuelwood at present. Other species such as Amooracucullata, Aegicerasmajus, Rhizophoramucronata, Hibiscus tilliaceus, Ceriopscandellana and Cynometraramiflora are also used as firewood in the Sundarbans. H. fomes fuel woods are used as raw material for the manufacture of hard boards Husssin and Acharya. ${ }^{6}$ Rhizophoraspp., Bruguiera spp., Ceriopsspp., Avicenniaspp., A. coniculatum, H. fomes and Xylocarpous spp. are the main uses for firewood San Tha Tun. ${ }^{13}$

Leaves of Nypafruticans is a major source as thatching material in southwest Bangladesh and ASEAN countries. The uses and 
economy of Nypa thatch is also popular in mangrove depending areas in Myanmar. Non-forest products such as honey and bee-wax are also produced in the areas. Honey made from Aegiseras is of high in quality and has a distinctive flavor. Husssin and Acharya ${ }^{6}$ estimated that $185,000 \mathrm{~kg}$ of honey and $44,400 \mathrm{~kg}$ of wax are extracted from mangrove forests in Sundabans annually.

Himilton ${ }^{9}$ reported that mangroves provide opportunities for education, scientific research, recreation and ecotourism. Mangroves have multiple uses. These are important sources of products such as timbers, various kinds of poles, firewood, charcoal, Nypa thatch, sugar, honey, paper-pulp, tennin, oil and many other living products such as fishes, shrimps, crabs, crocodiles, oysters etc. which are exploited by the riverine populations on a local scale and a global scale. In the present study, the products of fishery and forestry are the same uses in ASEAN countries. One of the mangrove plant, Avicennia is used as food and cheap nutritive feed for buffaloes, sheep, goats and camels in India, Pakistan, Persian Gulf region and Indonesia. ${ }^{14}$ Likewise, the seeds of Avicenniaofficinalis were used as feed for goats and cows at the study areas. Also, the seeds of Sonneratiaapetala and Avicennia marina were used as food for fish especially Ngadan(Silonia children).

Bruguieraspp., Excoecaria agallocha, Derris trifoliata, Acanthus ilicifolius, Xylocarpusspp., and Avicennia spp. are useful for indigenous medicine; Seeds of Avicennia have tonic effect, whereas Ceriops can produce hemostatic activity. Barks of Rhizophora species have astringent, antidiarrhoea and antemetic activities. Tender leaves of Acrostichum are used as a vegetable and a beverage is prepared from the fruits of Sonneratia spp. Extracts from mangroves seem to have a potential for human, animal and plant pathogens and for the treatment of incurable viral diseases like AIDS. ${ }^{11,15,16}$

In the study area, leaves and fruits of Clerodendroninerme are used for killing microbes in human body; leaves of Dolichandronespathacea for poison;seeds of Hygrophilaobovata for curing abscess, pustule; the while plant of Meropeangulata for muscle pain, paralysed, sprain; leaves of Plucheaindica for dysentery and seeds of Xylocarpusgranatum for treatment of cancer were revealed.

Malar $^{12}$ reported that $15 \%$ of mangroves are directly used and $85 \%$ are of indirect uses by the local population in Myeik. $5 \%$ of timber are harvested from Xylocarpousgranatum, Heritieralittoralis, Avicennia alba; $5 \%$ of fire wood are from Rhizophoraapiculata, R. mucronata Bruguieraparviflora and $5 \%$ of charcoal processing are from Rhizophoraapiculata, R. mucronata, and Bruguieraparviflora. In the present study, $100 \%$ of local people used the mangrove products directly, such as firewood, poles and thatches.

\section{Conclusion}

Mangrove forests are often a rich source of timber, fuel wood, honey, medicinal plants and other raw materials. Moreover, they attract tourists, fishers, hunters, hikers and birdwatchers providing a valuable realized or potential source of national income. So, mangrove ecosystems have an integral role to play in the provision of mangrove products and services that have value to coastal livelihoods, and coastal communities. The local people from three villages from southeastern Ayeyawady Delta depend most of their income and livelihoods on the mangrove forest directly or indirectly although the main economy of the local population is fishery. All the mangrove products were sold in the market by the local population and thus the village economies contribute to nearly all of the village level incomes. The fishery based products such as making dried shrimps, dried fishes, and fish paste were made by the local people particularly women. Moreover, the mangrove products such as charcoal, firewood, thatches and honey and others are also the supplementary income of the local people. So, the people from the three villages from Ayeyawady Dalta which are in the vicinity of mangrove forest have good income from the mangrove forest and fishery.

\section{Acknowledgements}

I would like to acknowledge my deepest respect and indebtedness to supervisor Dr. Htay Aung, Rector of Mawlamyine University for his valuable guidance, criticism and suggestion and for his kind permission to carry out this research work. Special thanks go to Dr. Aung Myat Kyaw Sein and Dr. Zaw Win, Pro-rectors of Mawlamyine University for their encouragement. I also wish to express my thanks Dr. San Tha Tun, Professor and Head of Department of Marine Science, for his kind permission of departmental facilities and needful assistance. I would like to express my great thanks to cosupervisor U Soe Htun, Professor and Head of Department of Marine Science, Mawlamyine University (Retd.) for his valuable advice and suggestion. I am deeply grateful to Dr. Mar Lar Aung, Professor and Head of Department of Botany, Mawlamyine University for providing facilities for laboratory apparatus, her permission and understanding for me through present work. I offer my sincerest appreciaton to U Aung Myo Myat, U Myo Naing and U Kyi Lin, Staff Officers, Ministry of Environmental Conservation and Forestry, Pyapon Township, Ayeyarwady Division, for their kind permission to study restored mangrove areas. My best thanks are also due to U Myo Naing, Staff Officer who offer bird photos used in this investigation. Thanks are also due to U Nyein Chan, Range Officer, U Moe Lwin, Deputy Ranger, U Phoe Phyu, Forester, U Kyaw Naing, Forest Guard and other staff members, Ministry of Environmental Conservation and Forestry, Pyapon Township, Ayeyarwady Region, for their assistance during my field works. I also especially want to thank U Thaung Naing Htay, plantation owner, Nauk-mee village, for his permission and assistance during field collection and many help.

\section{References}

1. Kathiresan K, Bingham BL. Biology of mangroves and mangrove ecosystems. Advances in Marine Biology. 2001;40:81-251.

2. Dixon JA. The value of mangrove ecosystems. Tropical Coastal Area Management Newsletter, 1989;4: 5-8.

3. Hong PN, San HT. Mangrove of Vietnam. IUCN, Bangkok, Thailand. $1993 ; 173 \mathrm{p}$.

4. Islam MA. Some Relevant Information about Sundarbans. Government of the People's Republic of Bangladesh. Sundarbans Forest Division. 1992. $19 \mathrm{p}$.

5. Chantarasri S. Intregrated Resource Development of the Sundarbans Reserved Forest. Fisheries Resources Management for the Sundarbans Reserved Forest. UNDP/FAO.BGD/84/056. Khulna, Bangladesh. 1994.

6. Hussain ZG, Acharya. Mnagroves of the Sundarbans; Vol. 2. Bangladesh. IUCN, Bangkok, Thailand. 1994.

7. Costanza R, d'Arge R, de Groot R, et al. 1997. The value of the world's ecosystem services and natural capital. Nature. 1997;387:253-260. 
8. Brown BE. Integrated Coastal Managenent: South Asia. Department of Marine Sciences and Coastal Management, University of Newcastle, Newcastal upon Tyne, United Kingdom. 1997.

9. Hamilton LS, Snedaken SC. Handbook for mangrove area management. 1984.

10. Bandaranayake WM. Traditional and medicinal uses of mangroves. Mangroves and Salt Marshes. 1998;2(3):133-148.

11. Kathiresan K. A review of studies on Pichavaram mangrove, southeast India. Hydrobiologia. 2000;430(1-3):185-205.

12. Mar Lar. Morphology and ecology of mangroves and associate in Myeikcoastal zone. Unpublished Ph.D Dissertation. Department of Botany, Yangon University, Yangon, Myanmar. 2009.
13. San Tha Tun. Species composition and structure of mangrove community along the U-To tidal creek in Chaung Tha. Unpublished Ph.D Dissertation. Department of Marine Science, Mawlamyine University, Mawlamyine, Myanmar. 2011.

14. Qasim SZ. Mangroves. In: Glimpses of the Indian Ocean, (University Press, Hyderabad), 1998; p.123-129.

15. Sathirathai S, Barbier EB. Valuating Mangrove Conservation in Southern Thailand. Contemporary Economic Policy. 2001;19(2):109-122.

16. Vannucci M. Indo-west pacific mangroves. In: "Mangrove ecosystems" (LacerdaL.Ded.) Springer-Verlag, Berlin. 2002. p. 123-215. 